\title{
Dietary probiotic live yeast modulates antioxidant enzyme activities and gene expression of sea bass (Dicentrarchus labrax) larvae
}

\author{
D. Tovar-Ramírez ${ }^{a, ~}{ }^{*}$, D. Mazurais ${ }^{a, b}$, J.F. Gatesoupe ${ }^{a, b}$, P. Quazuguel $^{a, b}$, C.L. Cahu ${ }^{a, b}$ and J.L. \\ Zambonino-Infante ${ }^{a, b}$
}

\author{
${ }^{a}$ Ifremer, Nutr. Aquaculture \& Genom. UMR1067, F-29280 Plouzane, France \\ ${ }^{\mathrm{b}}$ INRA, Nutr. Aquaculture \& Genom. UMR1067, F-64310 St Pee Sur Nivelle, France \\ *: Corresponding author : D. Tovar-Ramírez, Tel.: +52 6121238518; fax: +52 6121253625, email address : \\ dtovar04@cibnor.mx
}

\begin{abstract}
:
The main goal of this work was to determine the effect of dietary live yeast Debaryomyces hansenii on the enzymatic antioxidative status of sea bass Dicentrarchus labrax larvae. Growth, activity and expression of the main antioxidative enzymes: catalase (CAT), glutathione peroxidase (GPX) and superoxide dismutase (SOD), and heat shock protein (HSP70) were measured in sea bass larvae at 23 and 48 days after hatching. Larvae were fed on two microdiets: group one, fed microdiet containing live yeast and the control group fed microdiet without yeast. Heat shock protein 70 showed the same expression levels in both fish larvae fed yeast and the control diet. The group fed $D$. hansenii showed highest growth and lower activity and expression levels of GPX and SOD compared to fish fed control diet. In our work the differences in activity and gene expression patterns could only be attributed to the presence of yeast, assuming a possible involvement of superoxide anion retention in fish larvae, which could represent importance to the host to increase cell or tissue responsiveness to growth- and/or differentiation-enhancing factors.
\end{abstract}

Keywords: Antioxidant enzymes; Probiotics; Debaryomyces hansenii; Dicentrarchus labrax 


\section{Introduction}

Marine fish larvae are exposed to natural or induced stressors, some of them are responsible of reactive oxygen species (ROS) generation, which can promote morphological and/or physiological malfunctions. The metamorphosis stage is critical in this regard, due to high energetic consumption, and possible saturation of the antioxidant defenses (Solé et al., 2004). All aerobic organisms possess antioxidant enzymes capable to prevent membrane cell damages, enzyme inactivation and nucleic acid alterations. Antioxidant enzymes include superoxide dismutase (SOD) (EC 1.15.1.1.), catalase, (CAT) (EC 1.11.1.6.) and glutathione peroxidase (GPX) (EC 1.11.1.9.) that constitute the first line of antioxidant enzymatic defense. SOD catalyzes dismutation of superoxide radicals to hydrogen peroxide and oxygen; CAT catalyzes the breakdown of hydrogen peroxide to water and molecular oxygen. GPX, a selenium-dependent enzyme, decomposes peroxides using the peptide glutathione (GSH) as their co-substrate (Halliwell, 2006). Fish also possess non-enzymatic antioxidant defenses such as ubiquitous tripeptide glutathione, vitamins $E, C$ and $A$, carotenes, and ubiquinol (Wilhelm-Filho, 1996). Reactive oxygen species have been considered as the major mediators of oxygen cytotoxicity and also gained attention as important messengers stimulating cell division and demonstrating cellular signaling effects (Buetler et al., 2004).

Another important feature of the stress defenses at the time of fish metamorphosis was revealed by Deane and Woo (2003), who observed a dramatic increase in heat shock proteins (HSPs), HSP70 and HSP90, from 21 day post-hatching (dph) to $35 \mathrm{dph}$ in silver sea bream Sparus sarba. Heat shock proteins serve not only as molecular chaperones in case of thermal stress, but they act also against many environmental stresses, like extreme $\mathrm{pH}$, anoxia and high heavy metal concentration (Dahlhoff, 2004). HSPs are involved in the folding and translocation of newly synthesized proteins, as well as in the repair of damaged proteins denaturated by the stressor.

The use of probiotics is an effort to contribute to the healthy development of aquacultured animals and to understand the role played in the immune and antioxidant systems. Numerous studies have been focused on adult or juvenile fish antioxidant enzyme protection when ROS are generated by xenobiotics or fish exposure to pathogens (Reyes-Becerril et al., 2008a). Recent studies showed that dietary Debaryomyces hansenii stimulates both immune and antioxidant responses in juveniles of gilthead sea bream and in leopard grouper Mycteroperca rosacea (Reyes-Becerril et al., 2008ab) after exposure to pathogens. Concerning larval stages, the same strain of $D$. hansenii accelerated the maturation of the digestive system in sea bass (Tovar-Ramírez et al., 2004), but the mechanism of action has not been elucidated yet. A way to progress in this investigation may be to follow the response to such experimental treatment with some biomarkers of the physiological status and welfare indicators. For example, HSP70 gene expression was stimulated by dietary probiotics in gilthead sea bream subjected to $\mathrm{pH}$ stress at $47 \mathrm{dph}$ (Rollo et al., 2006). The main goal of the present study was evaluate the effect of dietary live $D$. hansenii on the enzymatic antioxidative status of sea bass larvae.

\section{Material and methods}

\subsection{Microorganisms}

The yeast Debaryomyces hansenii (CBS 8339) was kindly donated by Dr. R. VázquezJuárez and it was isolated from the gut of rainbow trout (Andlid et al., 1995). The strain CBS 8339 was cultured in yeast peptone-dextrose broth (YPD medium; SIGMA, Y1375) at $25^{\circ} \mathrm{C}$ with constant aeration until the early stationary phase $(24 \mathrm{~h})$. The cell suspension was centrifuged $\left(1000 \mathrm{~g}, 5 \mathrm{~min}, 4^{\circ} \mathrm{C}\right)$ and rinsed with sterile water for $5 \mathrm{~min}$ at $4^{\circ} \mathrm{C}$, the recovered 
cells were immediately incorporated into the dietary ingredients as described in Section 2.2 Animals and diets. The yeast viability was determined by counting the number of yeast plated on YPD agar (Sigma-Aldrich) supplemented with antibiotics (chloramphenicol, $1 \mathrm{mg} \mathrm{l}^{-}$ 1; polimyxin B sulfate, $1.6 \mathrm{mg} \mathrm{l}^{-1}$; amoxicillin, $2.5 \mathrm{mg} \mathrm{l}^{-1}$ ) (Sigma-Aldrich). Ten sea bass larvae were sampled at 23 and $48 \mathrm{dph}$ from each of the four replicates for microbiological counts, according to the method of Gatesoupe (1995). The yeast was counted on YPD agar supplemented with antibiotics listed above.

\subsection{Animals and diets}

European sea bass larvae (Dicentrarchus labrax) were provided by the marine farm Aquanord (Gravelines, France) and reared at IFREMER, Centre de Brest until $48 \mathrm{dph}$. Larvae were distributed into eight conical fiberglass tanks (35 I) at $2 \mathrm{dph}$, with initial stocking

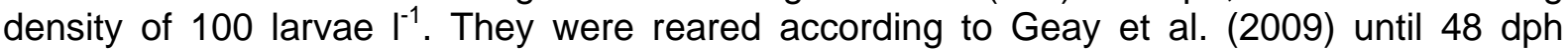
supplied with running seawater, which had been filtered through a sand filter, then passed successively through a tungsten heater and degassing column packed with plastic rings.

From 6 dph onwards, the larvae were fed on two compound diets; either containing or not $4.3 \%$ live $D$. hansenii, on a wet-weight basis (Table 1). The basal and yeast-supplemented diets were prepared according to Tovar-Ramírez et al. (2004). Protein concentration was $62.1 \%, 21 \%$ lipids, $12 \%$ ash related to $87 \%$ dry matter in both diets. The dietary ingredients, including yeast, were mixed with water, pelletized, and dried at $45^{\circ} \mathrm{C}$ for $20 \mathrm{~min}$. The pellets were sieved to obtain particles of two size ranges: $120-200$ and 200-400 $\mu \mathrm{m}$. Each diet was applied to four tanks. The larvae were fed in excess with belt feeders $18 \mathrm{~h}$ per day, with 120 $200 \mu \mathrm{m}$ particles from 6 to $20 \mathrm{dph}$, and with 200-400 $\mu \mathrm{m}$ particles thereafter.

\subsection{Sampling and dissection}

Larval growth for each dietary group was determined every week on the morning before

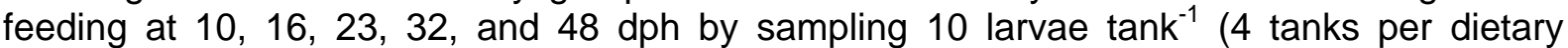
group). For enzymatic analysis, 100 larvae were collected from each tank on $23 \mathrm{dph}$ and 30 larvae from 36 to $48 \mathrm{dph}$. Another 60 larvae were collected for gene expression studies from each tank the same sampling days, following the method of Cahu and Zambonino-Infante (1994). Dissection produced a crude mixture of organs of each segment. The pancreatic segment contained pancreas, liver, heart, muscle, spine and a very short portion of intestine. Larvae for enzymatic assays and RNA extraction were frozen and stored at $-80^{\circ} \mathrm{C}$ until determination.

\subsection{Enzymatic measurements}

Pancreatic segments were homogenized in 5 volumes $(\mathrm{v} / \mathrm{w})$ of cold distilled water $\left(4^{\circ} \mathrm{C}\right)$; final volumes were between 1 and $2 \mathrm{ml}$. The enzymes catalase (CAT), glutathione peroxidase (GPX) and superoxide dismutase (SOD) were assayed in triplicate using 10, 20 and $10 \mu \mathrm{l}$ homogenate, respectively. CAT and GPX were assayed according to the SIGMA ${ }^{\circledR}$ kits protocols CAT100 and CGP1. SOD activity was assayed according to McCord and Fridovich (1969) where SOD competes with cytochrome c for superoxide ions generated by the hypoxanthine and xanthine oxidase reaction. SOD activity is determined by the level of inhibition of cytochrome $c$ reduction followed at 550nm. Activities were reported as units per $\mathrm{mg}$ of protein. Protein concentrations in each sample were determined according to Bradford (1976). 


\subsubsection{RNA extraction and cDNA cloning}

TRIzol ${ }^{\circledR}$ Reagent (Invitrogen, Breda, Netherlands) was used for total RNA extraction. Then, 1 $\mu \mathrm{g}$ total RNA was reverse-transcribed to cDNA with the QuantiTect ${ }^{\circledR}$ Reverse Transcription kit (Qiagen, Courtaboeuf, France). Primers and annealing temperatures are given in Table 2. Primers for CAT, GPX, SOD and HSP70 were obtained by alignment of most conserved regions from those sequences registered in Genbank.

The $50 \mu \mathrm{l}$ of amplification reaction mixture contained $50 \mathrm{ng}$ cDNA, $2.5 \mathrm{U}$ of Taq polymerase (Qiagen, Courtaboeuf, France), 40 nM dNTPs (Eurogentec, Seraing Belgium), 50 pmol of each primer, $1 \mathrm{X}$ buffer solution. PCR conditions were performed in a thermocycler (Techne, Staffordshire, UK) as follows: initial denaturation at $94^{\circ} \mathrm{C}$ for $30 \mathrm{~s}$, followed by 30 cycles including denaturation at $94^{\circ} \mathrm{C}$ for $1 \mathrm{~min}$, annealing at specific enzyme temperatures for 1.5 min, and 2 min elongation at $72^{\circ} \mathrm{C}$. A final extension cycle was performed at $72^{\circ} \mathrm{C}$ for 7 min.

Purified fragments were obtained according to the protocol of GFX ${ }^{\mathrm{TM}}$ (GE Healthcare, UK) and cloned according the protocol of Topo TA Cloning kit (Invitrogen, Breda, Netherlands) into TOP 10F' competent cells, using the PCR 2.1-TOPO as a vector. Plasmids were obtained by mini-prep according to UltraClean Mini Plasmid kit (MO-BIO, Carlsbad, USA) and sequenced by MilleGen (Labège, France). The resulting sequence for SOD and CAT was registered in Genbank under access number described in Table 2.

\subsubsection{Real Time-PCR}

cDNA pooled from the sea bass larvae fed yeast and control diet were used to construct standard curves for each analyzed gene using the primers described in Table 2 and conditions according to Mazurais et al. (2008). Standard curve allowed us to check efficiency for each cDNA amplification close to 2 (or 100\%). The gene Ef1a was chosen as a housekeeping gene because it did not exhibit any significant variation between groups fed different diets. The relative gene expressions were determined according to the $\Delta \Delta \mathrm{C}_{\mathrm{t}}$ method using IQ5 software (Bio-Rad). The $\Delta \Delta \mathrm{C}_{\mathrm{t}}$ method is also known as the comparative $\mathrm{C}_{\mathrm{t}}$ method where:
$\Delta \Delta \mathrm{C}_{\mathrm{t}}$
$=$
$[\Delta] \mathrm{C}_{\mathrm{t}, \mathrm{sample}}$
$[\Delta] \mathrm{C}_{\mathrm{t}}$
reference

here $\Delta \mathrm{C}_{\mathrm{t}, \text { sample }}$ is the $\mathrm{C}_{\mathrm{t}}$ value for any sample normalized to the endogenous housekeeping gene and $[\Delta] C_{t}$, reference is the $C_{t}$ value for the reference sample also normalized to the endogenous housekeeping gene. The IQ5 software allows automatic normalization of the $\mathrm{C}_{t}$ values to the housekeeping gene $(E f 1 \alpha)$. The $C_{t}$ values are also automatically compared between samples. Analysis of all individual samples was performed in triplicate

\subsubsection{Statistics}

Results are expressed as means \pm SD. One-way ANOVA was performed to determine the effects of dietary live yeast fed larvae versus control diet fed larvae on different enzyme and molecular approaches using the Statistica $v 7.1$ software (Statsoft, Tulsa, USA) and the level of statistical significance was set at $\mathrm{P} \leq 0.05$.

\section{Results}

The growth was not significantly different between the groups until $23 \mathrm{dph}$. The mean weights of sea bass fed the yeast-supplemented diet, was significantly higher than those of the control group at 32 and $48 \mathrm{dph}(\mathrm{P}<0.05$, Fig. 1$)$, despite that recovery of $D$. hansenii in 
solid YPD medium from those larvae fed yeast, diminished from $\sim 8 \times 10^{3}( \pm 5.4)$ to $\sim 200$ $( \pm 101)$ CFU at 23 and $48 \mathrm{dph}$, respectively. The yeast was not detected in the control group. Sea bass survival was not quantified because of high sampling rate, but it appeared to conform to normal standards.

Catalase specific activity in sea bass, and the relative gene expression levels were not significantly different between the groups at 23 and $48 \mathrm{dph}$ (Fig. 2). GPX specific activity was similar at $23 \mathrm{dph}$ in both groups, but at $48 \mathrm{dph}$, this activity increased significantly in the control group ( $P<0.05$, Fig. 2A). Contrary to the specific activity, the GPX gene expression in the control group was significantly higher than in the yeast-fed group at $23 \mathrm{dph}$, but this difference was not any longer observed at $48 \mathrm{dph}$ (Fig. 2B). Superoxide dismutase activity and gene expression level in the control group were significantly higher than in the yeastsupplemented group at $23 \mathrm{dph}(\mathrm{P}<0.05$, Fig. 3). At $48 \mathrm{dph}$, SOD specific activity and expression level were not significantly different between groups, nor was the HSP70 relative gene expression levels at 23 and $48 \mathrm{dph}$.

\section{Discussion}

A previous experiment showed already the doubling of the final mean weight of sea bass larvae fed a yeast-supplemented diet, compared to a control group (Tovar-Ramírez et al., 2004). Growth improvement has been also observed in adult and juvenile fish fed live yeast (Noh et al., 1994; Lara-Flores et al., 2003). Saccharomyces cerevisiae was also tested in Paralichthys olivaceus (Taoka et al., 2006), but, it was not possible to discriminate the contribution of yeast among the effect on growth (Gatesoupe, 2007). Yeast viability seems critical to observe such growth-promoting effect, since it was not observed when inactive yeast was incorporated into the feed (Métailler and Huelvan, 1993; Oliva-Teles and Gonçalves, 2001).

In our rearing conditions, yeast were not detected in the control group. The imputation of the effects of dietary yeast in sea bass larvae was thus easier than in rainbow trout fry, where autochthonous $D$. hansenii was naturally present (Aubin et al., 2005). In sea bass larvae, dietary $D$. hansenii promotes sea bass larvae growth and gut maturation by a possible influence of endoluminal yeast-secreted polyamines as was observed previously (TovarRamírez et al., 2004). Guzmán-Villanueva et al., (2007) also observed that the spotted sand bass, Paralabrax maculatofasciatus larvae fed with $D$. hansenii non-inhibited of ornithinedecarboxylase (ODC) activity, had precocious digestive maturation compared to $P$. maculatofasciauts larvae fed ODC-inhibited yeast with $\alpha$-difluoromethylornithine (DFMO). Ornithine decarboxylase, which catalyzes the formation of putrescine, is the rate-limiting enzyme in the biosynthesis of polyamines in cells.

In this study, sea bass larvae growth improvement was observed despite the poor yeast recovery in YPD agar from experimental fish at $48 \mathrm{dph}$. Besides, in other studies beneficial effects of yeast supplementation in terms of gut maturation, survival and prevention of vertebral malformations have been observed at the first stages of sea bass development (Tovar-Ramírez et al., 2004). Moreover, Gatesoupe (2007) mentioned that even if the intestinal transit is relatively short in fish, it is sufficient for digestion, and likely for the release of active compounds from yeast cells like polyamines, proteases and phosphatases (Zanello et al., 2009), which could be beneficial for the digestive process in fish larvae. 
The study of mechanisms behind oxidative stress in fish is an emerging field in aquaculture, resulting in an increase of the literature reports. It is important to know the different factors which affect the antioxidant systems in fish larvae, for example: Mourente et al. (1999) examined the antioxidant enzymes profiles in feed-deprived marine fish larvae during the early development in Dentex dentex; Fontagné et al. $(2006,2008)$ studied the characterization of antioxidant defense systems during the early development of Siberian sturgeon Acipenser baeri and rainbow trout Oncorhynchus mykiss larvae; and, the sand smelt larvae Atherina hepsetus was studied as a bioindicator of pollution in the Black Sea coastal waters by Rudneva and Zalevskaya (2004).

However, there are few reports concerning the effect of dietary components on the activity and gene expression of antioxidant enzymes during early development stages of marine fish larvae and fewer reports concerning the involvement of probiotics in the antioxidant system as feed additives. It has been observed that larvae antioxidant enzyme profiles exhibit variations from endogenous to exogenous feeding (Mourente et al., 1999; Peters and Livingstone 1996; Rudneva 1999).

Catalase activity increases when fish larvae are also exposed to determined levels of oxidant stressors or pathogen as was observed in Mycteroperca rosacea juveniles fed yeast, after exposure to the pathogen bacteria Aeromonas hydrophila (unpublished results). Probiotics may enhance phagocytic activity and increase the production of reactive oxygen metabolites by macrophages followed by an increased stimulation of CAT activity (Panigrahi et al., 2004; Reyes-Becerril et al., 2008a).

In our work, we observed that CAT activity and gene expression values were not different when sea bass larvae were fed either yeast or control diet at 23 or $48 \mathrm{dph}$. However, Fernández-Díaz et al. (2006) suggested that SOD, CAT and GPX showed diet and age dependence in their response when Solea senegalensis larvae were fed with Artemia compared with a microencapsulated diet. Kalaimani et al. (2008) also observed increased CAT activity when Artemia nauplii feed concentration increase in Lates calcarifer larvae from 15 at $25 \mathrm{dph}$.

In this study, oxidative stress was observed in sea bass larvae fed the control diet, represented by an increase in GPX activity at $48 \mathrm{dph}$ and gene expression levels in both GPX and SOD at $23 \mathrm{dph}$. SOD catalyses the dismutation of superoxide anion resulting in oxygen and $\mathrm{H}_{2} \mathrm{O}_{2}$, which may also serves as substrate to GPX. The reduction of $\mathrm{H}_{2} \mathrm{O}_{2}$ derived from oxidative metabolism as well as peroxides from oxidation of lipids is considered the most effective enzyme against lipid peroxidation and its activity depends of $\mathrm{H}_{2} \mathrm{O}_{2}$ concentration, because it is considered as complementary to CAT activity when substrate is in low concentrations (Pérez-Campo et al., 1993; Halliwell and Gutteridge, 2000). In our work, the differences in activity patterns and gene expression could be only attributed to the $4.3 \%$ of yeast in the experimental diet, as biochemical compositions of both diets were similar. We have previously demonstrated the effect of dietary live $D$. hansenii on the stimulation of digestive enzymes in sea bass larvae, which may result in a better utilization of the compound diet by the larvae (Tovar-Ramírez et al., 2002, 2004). Thus, the steady state of the biomarkers in the yeast-fed groups could reflect a consequent improvement in health and oxidative status, compared to the control group, in which the fluctuation of GPX and SOD might be caused to cope with the high oxidative stress at metamorphosis, as showed by Fernández-Díaz et al. (2006) and Kalaimani et al. (2008). Then, this increased energy expenditure could account for the difference observed in growth. Similar superoxide dismutase patterns were observed in grouper Epinephelus coioides fed the probiotic 
Lactobacillus plantarum when its activity decreased in 2 and 4 weeks after probiotic feeding compared to the control diet (Son et al., 2009). This decrease in SOD activity was interpreted by a possible retention of the superoxide anion level or by a conversion into the singlet oxygen and/or hydroxyl radicals to enhance the microbial-killing capacity of phagocytes. Another possible explanation could arise from the physiological importance of superoxide anion retention as a local molecular signal; during the ontogeny of cells and tissues, superoxide may serve to increase the responsiveness to growth-promoting and/or differentiation-enhancing factors (Buetler et. at., 2004). This hypothesis should be further explored in the particular case of yeast-fed sea bass larvae, where growth was strongly stimulated, while the activity and gene expression of SOD and GPX remained at stable levels, in contrast to sea bass larvae fed the control diet.

Heat shock protein 70 showed similar gene expression levels in both fish larvae fed yeast and control diet (Fig 5). The expression of HSP70 is involved in numerous biological processes not only related to heat exposition, but for example, a chemical shock or high fish population density exposure (Gornati et al., 2004). This biomarker may require stressful conditions to reveal the effect of dietary treatments, like the $\mathrm{pH}$ stress test performed by Rollo et al. (2006). Other HSPs also should be considered. Solé et al. (2004) suggested that HSP60 could become more important than HSP70 in ongrowing fish. Deane and Woo (2003) emphasized the importance of HSP9O in the corticosteroid complex during larval development.

In conclusion, the present study indicates that live marine yeast $D$. hansenii CBS 8339 positively enhances growth performance and antioxidant status of sea bass larvae by means of preventing oxidative stress, and by maintaining a stable activity and gene expression of SOD and GPX. Such biomarkers seem of utmost importance during marine fish larval development, when the animals required diets particularly rich in highly unsaturated fatty acids, while they may be exposed to anoxia and reoxygenation processes.

\section{Acknowledgements}

The first author received a sabbatical grant from Consejo Nacional de Ciencia y Tecnología, México (CONACYT exp. 81181).

\section{References}

Andlid, T., Vázquez-Juárez, R., Gustafsson, L., 1995. Yeast colonizing the intestine of rainbow trout (Salmo gairdneri) and turbot (Scophthalmus maximus). Microb. Ecol. 30, 321334.

Aubin, J., Gatesoupe, F.-J., Labbé, L., Lebrun, L., 2005. Trial of probiotics to prevent the vertebral column compression syndrome in rainbow trout (Oncorhynchus mykiss Walbaum). Aquacult. Res. 36, 758-767.

Bradford, M.M., 1976. A rapid and sensitive method for the quantitation of microgram quantities of protein utilizing the principle of protein-dye binding. Analytical Biochemistry 72 , 248-254. 
Buetler, T.M., Krauskopf, A., Ruegg, U.T., 2004. Role of superoxide as a signaling molecule. News Physiol Sci 19: 120_123.

Cahu, C.L., Zambonino-Infante, J.L., 1994. Early weaning of sea bass (Dicentrarchus labrax) larvae with a compound diet: effect on digestive enzymes. Comp. Biochem. Physiol. 109, 213-222.

Dahlhoff, E.P., 2004. Biochemical indicators of stress and metabolism: Applications for Marine Ecological Studies. Annu. Rev. Physiol. 66:183-207.

Deane, E.E., Woo, N.Y.S., 2003. Ontogeny of thyroid hormones, cortisol, hsp70 and hsp90 during silver sea bream larval development. Life Sciences 72, 805-818.

Fernández-Díaz, C., Kopecka, J., Cañavate, J.P., Sarasquete, C., Solé, M., 2006. Variations on development and stress defences in Solea senegalensis larvae fed on live and microencapsulated diets. Aquaculture 251, 573- 584.

Fontagné, S., Bazin, D., Brèque, J., Vachot, C., Bernarde, C., Rouault, T., Bergot, P., 2006. Effects of dietary oxidized lipid and vitamin A on the early development and antioxidant status of Siberian sturgeon (Acipenser baeri) larvae. Aquaculture 257, 400-411.

Fontagné, S., Lataillade, E., Brèque, J., Kaushik, S., 2008. Lipid peroxidative stress and antioxidant defence status during ontogeny of rainbow trout (Oncorhynchus mykiss). British Journal of Nutrition, 100, 102-111.

Gatesoupe, F.J., 1995. A method for the early assessment of the quality of turbot larvae. Aquacult. Int. 3, 150- 154.

Gatesoupe, F.J., 2007. Live yeasts in the gut: Natural occurrence, dietary introduction, and their effects on fish health and development. Aquaculture 267, 20-30.

Geay, F., Darias, M.J., Santigosa, E., Desbruyeres, E., Quazuguel, P., Zambonino-Infante, J.L., Cahu, C.L., Mazurais, D., 2009. Cloning of endothelin-1 (ET-1) from European sea bass (Dicentrarchus labrax) and its gene expression analysis in larvae with retinoic acid-induced malformations. Aquaculture, 287 (1-2): 169-173.

Gornati, R., Papis, E., Rimoldi, S., Terova, G., Saroglia, M., Bernardini, G., 2004. Rearing density influences the expression of stress-related genes in sea bass (Dicentrarchus labrax, L.), Gene 341, 111-118 (2004).

Guzmán-Villanueva, L., Tovar-Ramírez, D., Civera-Cerecedo, R., 2007. Effect of wild and ornithine decarboxylase deficient Debaryomyces hansenii, on Paralabrax maculatofasciatus larvae development, Caribbean and Latin American Aquaculture 2007, San Juan Puerto Rico, 6 - 9 November.

Halliwell, B., Gutteridge, J.M.C., 2000. Free Radicals in Biology and Medicine, 3a ed. Oxford University Press, Oxford.

Halliwell, B., 2006. Reactive Species and Antioxidants. Redox Biology Is a Fundamental Theme of Aerobic Life. Plant Physiology 141:312-322.

Kalaimani, K., Chakravarthy, N., Shanmugham, R., Thirunavukkarasu, A.R., Alavandi, S.V. Santiago, T. C., 2008. Anti-oxidant status in embryonic, post-hatch and larval stages of Asian seabass (Lates calcarifer), Fish Physiol Biochem (2008) 34:151-158 DOI 10.1007/s10695007-9155-4. 
Lara-Flores, M., Olvera-Novoa, M.A., Guzmán-Méndez, B.E., López-Madrid, W., 2003. Use of the bacteria Streptococcus faecium and Lactobacillus acidophilus, and the yeast Saccharomyces cerevisiae as growth promoters in Nile tilapia (Oreochromis niloticus).

Aquaculture 216, 193-201.

Mazurais, D., Darias, M.J., Gouillou-Coustans, M.F., Le Gall, M.M., Huelvan, C., Desbruyeres, E., 2008. Dietary vitamin mix levels influence the ossification process in European sea bass (Dicentrarchus labrax) larvae. Am. J. Physiol. Regul. Integr. Comp. Physiol. 294, R520-R527.

Métailler, R., Huelvan, C., 1993. Uitilisation des levures dans l'alimentation du juvénile de bar (Dicentrarchus labrax). In: Kaushik, S.J., Luquet, P. (Eds.), Fish Nutrition in Practice Les Colloques, vol. 61. Institut National de la Recherche Agronomique, Paris, pp. 945-948.

Mourente, G., Tocher, D.R., Diaz, E., Grau, A., Pastor, E., 1999. Relationships between antioxidants, antioxidant enzyme activities and lipid peroxidation products during early development in Dentex dentex eggs and larvae. Aquaculture 179, 309-324.

Noh, S.H., Han, K.,Won, T.H., Choi, Y.J., 1994. Effect of antibiotics, enzyme, yeast culture and probiotics on the growth performance of Israeli carp. Korean J. Anim. Sci. 36, 480- 486.

Oliva-Teles, A., Gonçalves, P., 2001. Partial replacement of fishmeal by brewers yeast (Saccharomyces cerevisiae) in diets for sea bass (Dicentrarchus labrax) juveniles. Aquaculture 202, 269- 278.

Panigrahi, A., Kiron, V., Kobayashi, T., Puangkaew, J., Satoh, S., Sugita, H., 2004. Immune responses in rainbow trout Oncorhynchus mykiss induced by a potential probiotic bacteria Lactobacillus rhamnosus JCM 1136. Veterinary Immunology and Immunopathology 102, 379-88.

Pérez-Campo, R., López-Torres, M., Rojas, C., Cadenas, S., Barja, G., 1993. A comparative study of free radicals in vertebrates-I. Antioxidant enzymes. Comp. Biochem. Physiol. 105B, 745-749.

Peulen, O., Deloyer, P., Grandfils, C., Loret, S., Dandrifosse, G., 2000. Intestinal maturation induced by spermine in young animals. Livest. Prod. Sci. 66, 109-120.

Peters, L.D., Livingstone, D.R., 1996. Antioxidant enzyme activities in embryologic and early larval stages of turbot. Journal of Fish Biology, Vol 49, Issue 5, Pages986-997.

Reyes-Becerril, M., Salinas, I., Cuesta, A., Meseguer, J., Tovar-Ramírez D., Ascencio-Valle, F., Esteban, M.A., 2008a. Oral delivery of live yeast Debaryomyces hansenii modulates the main innate immune parameters and the expression of immune-relevant genes in the gilthead seabream (Sparus aurata L.). Fish and Shellfish Immunology 25, 731-739.

Reyes-Becerril, M., Tovar-Ramírez, D., Ascencio-Valle, F., Civera-Cerecedo R., GraciaLópez, V., Barbosa-Solomieu, V., 2008b. Effects of dietary live yeast Debaryomyces hansenii on the immune and antioxidant system in juvenile leopard grouper Mycteroperca rosacea exposed to stress. Aquaculture 280, 39-44.

Rollo, A., Sulpizio, R., Nardi, M., Silvi, S., Orpianesi, C., Caggiano, M., Cresci, A., Carnevali, O., 2006. Live microbial feed supplement in aquaculture for improvement of stress tolerance. Fish Physiology \& Biochemistry 32, 167-177. 
Rudneva, I.I., 1999. Antioxidant system of Black Sea animals in early development. Comp Biochem Physiol C 122 265-271.

Rudneva, I.I., Zalevskaya, I. N., 2004. Larvae of Sand Smelts (Atherina hepsetus L.) as a Bioindicator of Pollution in the Black Sea Coastal Waters. Russian Journal of Ecology. 35 (2). 86-90 (translated from Ekologiya, No. 2, 2004, pp. 107-112).

Solé, M., Potrykus, J., Fernández Díaz, C., Blasco, J., 2004. Variations on stress defences and metallothionein levels in the Senegal sole, Solea senegalensis, during early larval stages. Fish Physiology \& Biochemistry 30, 57-66.

Son, V.M., Chin-Chyuan, C., Mi-Chen, W., Yuan-Kuang, G., Chiu-Hsia, C., Winton, C., 2009. Dietary administration of the probiotic, Lactobacillus plantarum, enhanced the growth, innate immune responses, and disease resistance of the grouper Epinephelus coioides. Fish \& Shellfish Immunology 26, 691-698

Taoka, Y., Maeda, H., Jo, J.Y., Jeon, M.J., Bai, S.C., Lee, W.J., Yuge, K., Koshio, S., 2006. Growth, stress tolerance and non-specific immune response of Japanese flounder Paralichthys olivaceus to probiotics in a closed recirculating system. Fish. Sci. 72, 310-321.

Tovar, D., Zambonino, J., Cahu, C., Gatesoupe, F.J., Vázquez, J. R., Lésel, R., 2002. Effect of live yeast incorporation in compound diet on digestive enzyme activity in sea bass (Dicentrarchus labrax) larvae. Aquaculture 204, 113-23.

Tovar-Ramírez, D., Zambonino-Infante, J., Cahu, C., Gatesoupe, F.J., Vázquez-Juárez, R., 2004. Influence of dietary live yeast on European sea bass (Dicentrarchus labrax) larval development. Aquaculture 234, 415-27.

Waché, Y., Auffray, F., Gatesoupe, F.J., Zambonino, J., Gayet, V., Labbé, L., Quentel, C., 2006. Cross effects of the strain of dietary Saccharomyces cerevisiae and rearing conditions on the onset of intestinal microbiota and digestive enzymes in rainbow trout, Onchorhynchus mykiss, fry. Aquaculture 258, 470-478.

Wilhelm Filho, D., 1996. Fish antioxidant defenses - a comparative approach. Braz J Med Biol Res 29:1735-1742.

Zanello, G., Meurens, F., Berri, M., Salmon, H., 2009. Saccharomyces boulardii effects on gastrointestinal diseases. Curr. Issues Mol. Biol. 11: 47-58.

\section{Tables}

Table 1. Composition of the experimental compound diets

\begin{tabular}{llcc}
\hline $\begin{array}{l}\text { diet } \\
\text { Ingredients }\end{array}$ & $\begin{array}{l}\text { Control } \\
(\mathrm{g} / \mathrm{kg} \mathrm{diet})\end{array}$ & $\begin{array}{c}\text { Yeast } \\
(\mathrm{g} / \mathrm{kg} \mathrm{diet})\end{array}$ & $\begin{array}{c}\text { supplemented } \\
\text { Fish meal }\end{array}$ \\
Hydrolysed fish meal (CPSP) $^{\mathrm{a}}$ & 550 & 507 \\
D. hansenii & 120 & 120 \\
Lecithin $^{\mathrm{b}}$ & 0 & 43 \\
Vitamin mixture $^{\mathrm{c}}$ & 200 & 200 \\
Mineral mixture $^{\mathrm{d}}$ & 80 & 80 \\
Betaine & 40 & 40 \\
\hline
\end{tabular}


a All dietary ingredients were commercially obtained: fish meal (La Lorientaise, Lorient, France), hydrolysed fish meal (CPSP, Soluble Fish Protein Concentrate, Sopropêche, Boulogne sur mer, France), Soyabean lecithin (Ets louis François, saint Maur des Fossés, France).

${ }^{\mathrm{b}}$ Wet weight equivalent to $1.1 \%$ dry weight.

${ }^{\mathrm{C} C}$ Composition $/ \mathrm{kg}$ of the vitamin mixture: choline concentrate $50 \%, 200 \mathrm{~g}$; all-rac-a-tocopherol acetate (500 Ul/g) $10 \mathrm{~g}$; cholecalciferol (500,000 Ul/g) $0.50 \mathrm{~g}$; niacin $1 \mathrm{~g}$, D-calcium pantothenate $2 \mathrm{~g}$; thiamin $100 \mathrm{mg}$; riboflavine $0.4 \mathrm{~g}$; pyridoxine $\mathrm{HCl} 300 \mathrm{mg}$; ascorbic acid 20 g; folic acid $100 \mathrm{mg}$; cyanocobalamin $1 \mathrm{~g}$; biotin $1 \mathrm{~g}$; menadione1 g; meso-inositol $30 \mathrm{~g}$; cellulose $732.1 \mathrm{~g}$.

${ }^{\mathrm{d}}$ Composition/kg of the mineral mixture: $90 \mathrm{~g} \mathrm{KCl}, 40 \mathrm{mg} \mathrm{KIO} 3,500 \mathrm{~g}$ CaHPO4 2H2O, $40 \mathrm{~g}$ $\mathrm{NaCl}, 3 \mathrm{~g}$ CuSO4 5H2O,4 g ZnSO4 7H2O, $20 \mathrm{mg} \mathrm{CoSO} 4$ 7H2O, $20 \mathrm{~g} \mathrm{FeSO} 4$ 7H2O, $3 \mathrm{~g}$ MnSO4 H2O, $215 \mathrm{~g} \mathrm{CaCO}, 124 \mathrm{~g} \mathrm{MgSO} 4$ 7H2O, and $1 \mathrm{~g} \mathrm{NaF}$.

Table 2. Oligonucleotide primer sequences

\begin{tabular}{lll}
\hline Gene & Accession Number & Forward and reverse primers \\
\hline SOD* $^{*}$ & & F: AGGCATGTTGGAGACCTGGG \\
HSP70* & & R: TTGCCTGTCTTTAGACTCTC \\
& & F: GACGTGTCCATCCTGACCAT \\
CAT* $^{*}$ & & R: TCGATGCCCTCAAACAGAGA \\
SODq & FJ860004 & R: CTTGTAGTGGAACTTGCAGTAG \\
& & F: GTTGGAGACCTGGGAGATGT \\
HSP70q & AY423555** & R: CTCCTCATTGCCTCCTTTC \\
& & F: CCATCCTGACCATCGAAGAC \\
CATq & FJ860003 & F: ATGGTCTTGGCCCTCTCACA \\
& & R: AGTGGAACTTGCAGTAGAAACG \\
GPXq & FM013606.1*** & F: AGTTAATCCGGAATTCGTGAGA \\
& & R: TGAGTGTAGTCCCTGGTTGTTG \\
Ef1q & AJ866727 & F: GCTTCGAGGAAATCACCAAG \\
& & R: CAACCTTCCATCCCTTGAAC \\
\hline
\end{tabular}

* Oligonucleotide primers used for primary PCR

${ }^{* *}$ Gornati et al. (2004)

*** expressed sequence tags

q Oligonucleotide primers used for real time PCR 
Figures

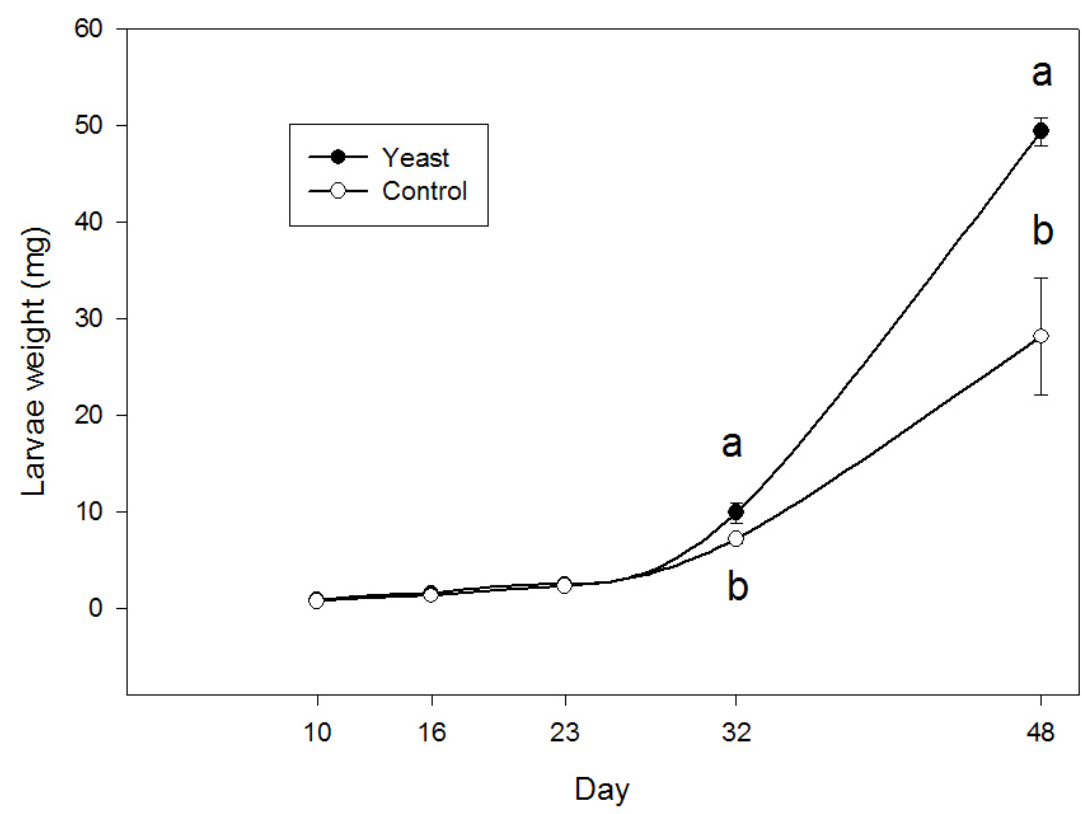


Fig. 1. Average body weight (mg) in D. labrax larvae fed non-supplemented (control) and Debaryomyces hansenii-supplemented diets. Data represent the means \pm SE $(n=40)$. Means \pm S.D. with different superscripts for the 32 and $48 \mathrm{dph}$ are significantly different $(\mathrm{P}<0.05)$. 

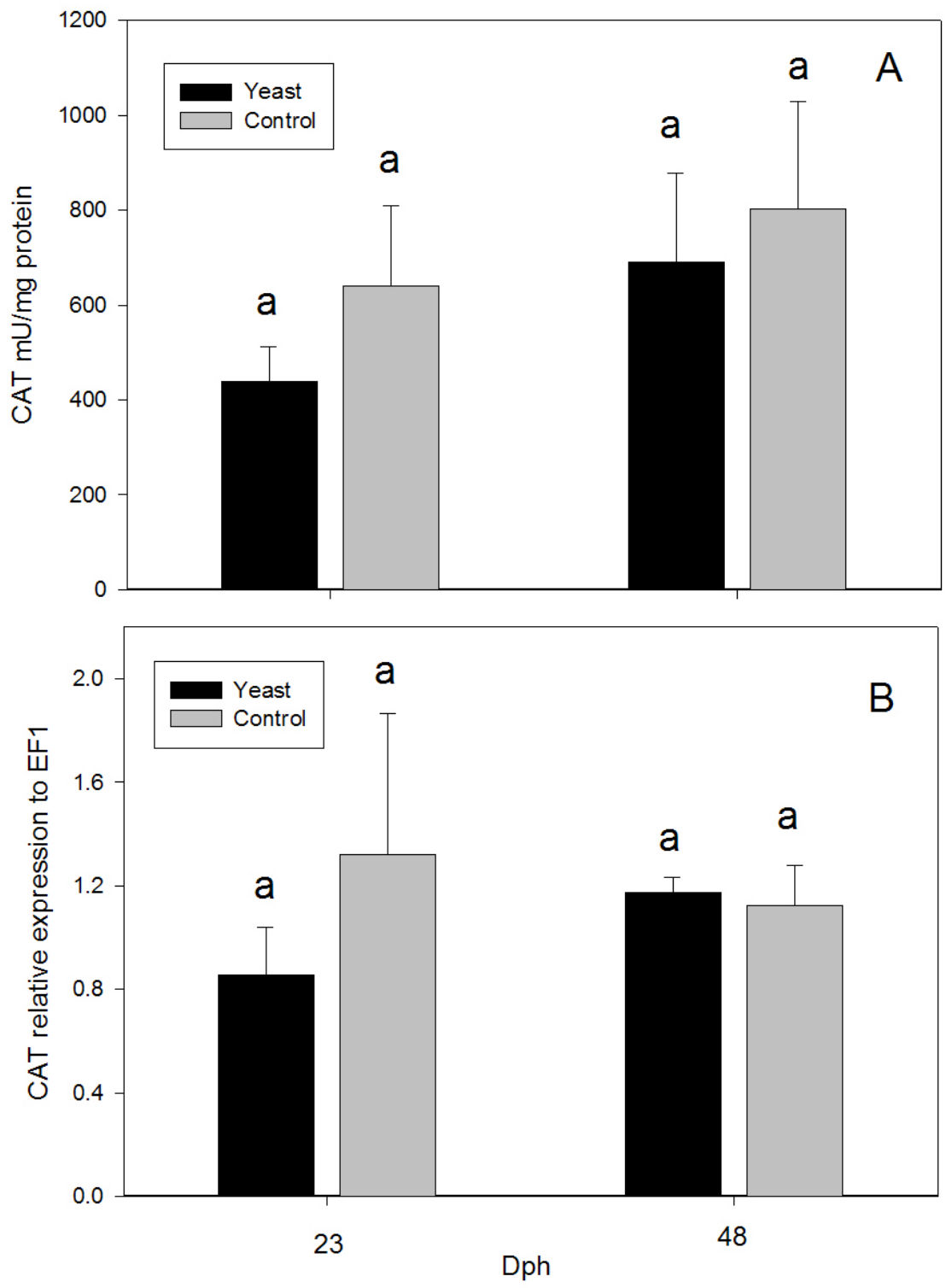

Fig. 2. Catalase activity (A) and CAT relative expression levels to EF1 (B) in whole D. labrax larvae fed a control diet and Debaryomyces hansenii-supplemented diet, at 23 and $48 \mathrm{dph}$. Means means $\pm S D(n=4)$ for the same day with different superscripts are significantly different $(P<0.05)$. 

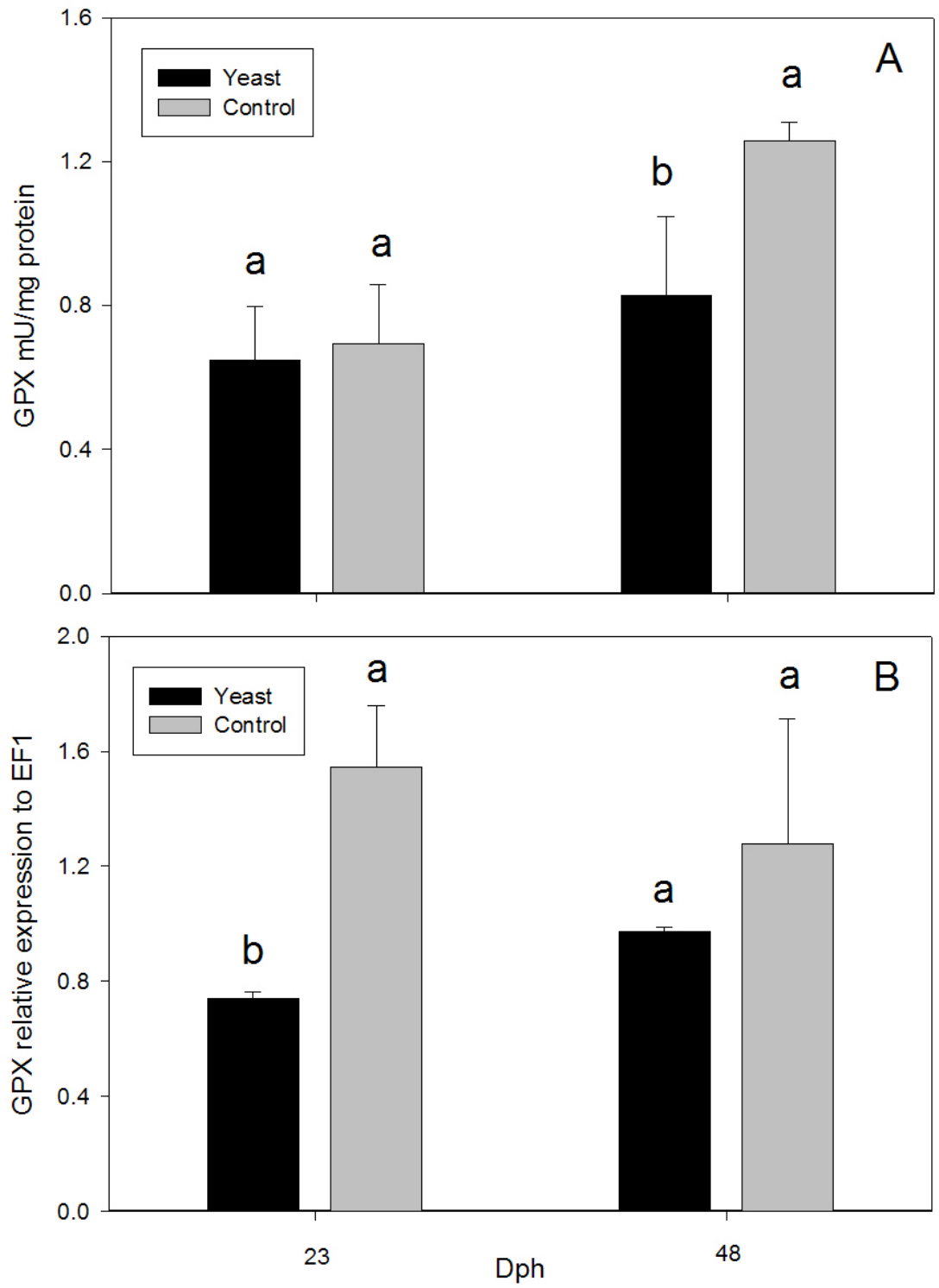

Fig. 3. Glutathione peroxidase activity (A) and GPX relative expression levels to EF1 (B) in whole $D$. labrax larvae fed a control diet and Debaryomyces hansenii-supplemented diet, at 23 and $48 \mathrm{dph}$. Means means \pm SD $(n=4)$ for the same day with different superscripts are significantly different $(P<0.05)$. 

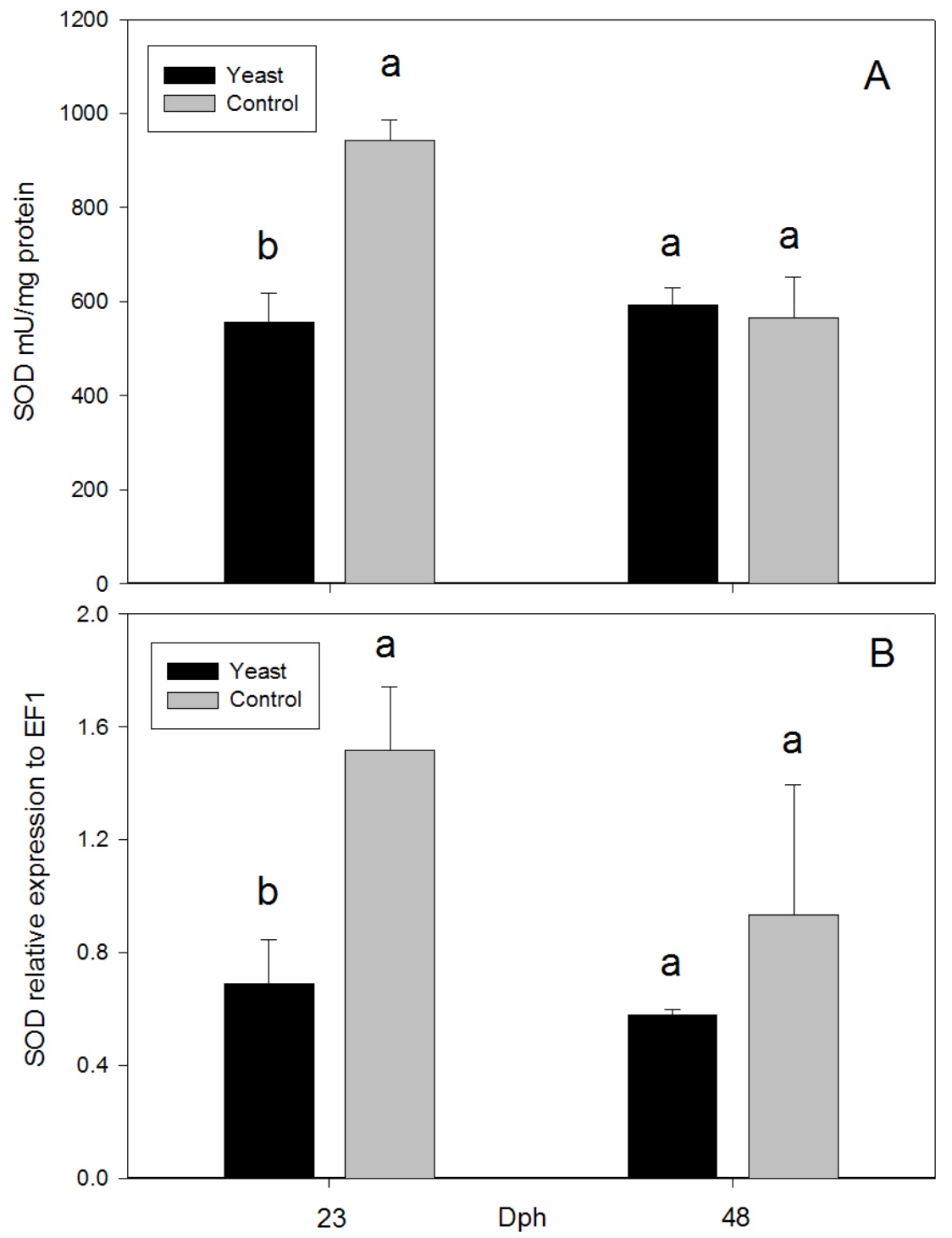

Fig. 4. Superoxide dismutase activity (A) and SOD relative expression levels to EF1 (B) in whole $D$. labrax larvae fed a control diet and Debaryomyces hansenii-supplemented diet, at 23 and $48 \mathrm{dph}$. Means means \pm SD $(n=4)$ for the same day with different superscripts are significantly different $(P<0.05)$. 


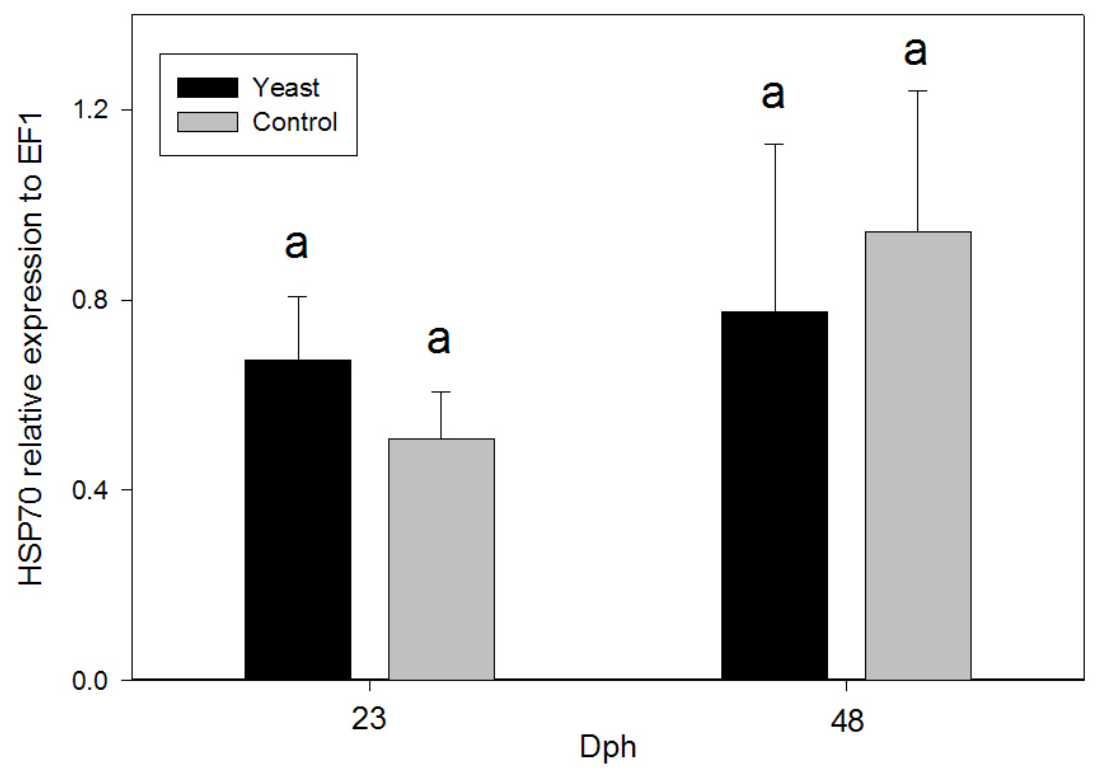

Fig. 5. Heat shock protein 70 relative expression levels to EF1 in whole $D$. labrax larvae fed a control diet and Debaryomyces hansenii-supplemented diet, at 23 and $48 \mathrm{dph}$. Means means $\pm S D(n=4)$ for the same day with different superscripts are significantly different $(P<0.05)$. 